\title{
Peran Keluarga Muda Jawa terhadap Penggunaan Bahasa Jawa pada Ranah Keluarga di Lingkungan Perkampungan Kota Semarang
}

\author{
M. Suryadi, \\ Fakultas Ilmu Budaya, Universitas Diponegoro, \\ Email: mssuryadi07@gmail.com
}

\begin{abstract}
The research aims is to determine the strength and the role of families, especially the families of the village who were used Javanese Language. Nowadays, the Javanese language the developed is the reflection of family concern, especially the role of parents in inheriting the use of Javanese Language (normative-prescriptive). The research location is in Semarang City. The method that used to obtain data was the method refer to: observation, record, and method of proficient: participant, interviews. Data analysis used descriptive-quantitative method, i.e. Ervin-Tripp alternation rule (1972). The result of this research that the role of family is very influential on the mastery and use of Javanese Language, as well as coloring the Javanese Language on the present-day. The family has three main roles, namely (1) the gateway to the introduction of the Javanese Language, (2) the gateway to learning Javanese Language, and (3) the gateway to preservation of Javanese.
\end{abstract}

Keywords: Javanese, role, young family, preservation.

\section{Intisari}

Tujuan penelitian ini adalah untuk mengetahui kekuatan dan peran keluarga, terutama keluarga perkampungan dalam penggunaan bahasa Jawa. Bahasa Jawa yang berkembang saat ini sebagai cerminan kepedulian keluarga, terutama peran orang tua dalam mewariskan penggunaan bahasa Jawa, yang semestinya (normatif-preskriptif). Lokasi penelitian berada di Kota Semarang. Metode yang digunakan untuk memperoleh data adalah metode simak: observasi, catat, rekam dan metode cakap: partisipan, wawancara. Analisis data menggunakan metode deskriptif-kualitatif, dengan memanfaatkan kaidah alternasi ErvinTripp (1972). Temuan penelitian bahwa peran keluarga sangat berpengaruh terhadap penguasaan dan penggunaan bahasa Jawa, sekaligus yang mewarnai bentuk bahasa Jawa kekinian. Keluarga memiliki tiga peran utama, yakni sebagai (1) pintu gerbang pengenalan bahasa Jawa, (2) pintu gerbang pembelajaran bahasa Jawa, dan (3) pintu gerbang pelestarian bahasa Jawa.

Kata kunci: bahasa Jawa, peran, keluarga muda, pelestarian

\section{Pendahuluan}

Bahasa Jawa sebagai bahasa ibu bagi masyarakat Jawa memiliki sejarah yang cukup panjang. Daya tahan penggunaan bahasa Jawa, telah terbukti melalui area wilayah persebaran bahasa Jawa yang cukup luas, migrasi bahasa Jawa yang sangat kompleks, jumlah penutur yang paling banyak bila dibandingkan dengan penutur-penutur bahasa daerah di Nusantara. 
Salah satu daya tahan yang cukup kuat adalah rasa memiliki yang diikat dengan rasa cinta dan bangga dengan bahasa Jawa itu sendiri. Sebagai sarana penyampai rasa emosi, keindahan, kasih sayang, dan harkat sebagai orang Jawa. Salah satu peran utama dimainkan keluarga, sebagai pintu gerbang awal mengenali bahasa Jawa secara emotif. Kekuatan emotif terpancar pada kosakata yang tersimpan dalam multi tataran: ngoko, krama, dan krama inggil.

Tolak ukur penguasaan terhadap pemakaian bahasa Jawa secara baik dan benar, pada intinya terletak terhadap kemampuan untuk memilih dan memilah kosakata bahasa Jawa secara cermat dan tepat. Kemampuan memilih dan memilah kosakata terkait erat dengan penguasaan kosakatanya, semakin kaya penguasaan kosakatanya diharapkan semakin leluasa dan tepat dalam memilih dan memilah kata yang digunakan dalam tuturan, sebaliknya semakin miskinnya kosakata yang dikuasainya beresiko terhadap penempatan penggunaan kosakata dalam tuturan, yang dimungkinkan akan munculnya tumpang tindih penggunaan kata dalam tuturan.

Penguasaan kosakata tidak dapat dilepaskan dari peran keluarga sebagai lembaga informal, sekaligus sebagai pintu gerbang pertama kali seorang anak mengenal bahasanya melalui kasih sayang orang tuanya. Peran orang tua sangat dominan, terutama peran ibu sebagai motor kasih sayang dalam keluarga terutama pada anak-anaknya. Kuatnya peran keluarga akan memberikan warna bahasa Jawa yang ada saat ini. Bentuk penggunaan bahasa Jawa di lingkungan keluarga sebagai miniatur penggunaan dan penguasaan bahasa Jawa bagi penutur Jawa.

Seberapa jauhkah peran keluarga dalam menentukan masa depan penggunaan bahasa Jawa bagi penuturnya dapat terukur dan tampak dari wujud penggunaan bahasa Jawa saat ini. Manakala peran keluarga sangat tinggi dalam pemahaman dan pewarisan bahasa Jawa maka dapat diperkirakan penggunaan bahasa Jawa oleh penuturnya cukup atau sangat baik. Sebaliknya, manakala peran keluarga sangat rendah terhadap pemahaman dan penggunaan bahasa Jawa maka dapat dipastikan perkembangan bahasa Jawa semakin merosot, dan akan menimbulkan kekhawatiran terhadap masa depan bahasa Jawa.

Masihkah peran keluarga dapat diandalkan dalam menjaga perkembangan bahasa Jawa saat ini. Kerisauan ini sekaligus digunakan sebagai rumusan masalah dalam penelitian, bagaimana peran keluarga dalam mengemban misinya untuk mengenalkan, mempelajari, dan mewariskan bahasa Jawa bagi anak keturunannya. 
Fokus kajian pustaka pada penelitian ini memanfaatkan dan mengoptimalkan hasilhasil penelitian, karya ilmiah, dan jurnal yang terkait erat dengan persoalan kehidupan bahasa Jawa dalam ranah keluarga. Adapun kajian yang dimanfaatkan dalam penelitian ini, sebagai berikut.

Purwoko (2008) dalam karyanya ini menyoroti penggunaan bahasa Jawa ngoko yang terjadi masyarakat lapis bawah (rakyat kebanyakan - tiyang alit) dengan lokasi penelitian kawasan perkotaan Semarang. Hasil penelitian tersebut mengungkapkan bahwa penggunaan kode ngoko oleh masyarakat kelas bawah selain faktor linguistik, tidak dapat dilepaskan oleh faktor sosial, budaya, politik, psikologi, demografi, dan profil penutur aslinya.

Bernstein (1972) mengemukakan bahwa pemerolehan bahasa termasuk di dalamnya pembelajaran sebuah bahasa sangat tergantung pada sosialisasi yang dilaksanakan oleh keluarga. Sosialisasi yang dilakukan oleh keluarga tersebut akan menghasilkan kode linguistik, antara lain berwujud pilihan kata, intonasi, strategi wacana, dan cara bicara (cf. Calefato, 2009). Ranah keluarga memiliki peran penting dalam pemerolehan bahasanya, sekaligus sebagai pintu utama dalam memahami, mengaplikasikan dalam kehidupan struktur masyarakat terkecil.

Sudaryanto (1991) menyatakan bahwa penggunaan bahasa Jawa banyak ditemui pada ranah keluarga. Pada ranah keluarga inilah penggunaan bahasa Jawa sangat ditentukan oleh cita rasa masing-masing keluarga, sehingga secara kualitas maupun kuantitas masing-masing keluarga akan berbeda dalam penggunaan tuturan Jawanya. Kualitas dan kuantitas tersebut berkorelasi dengan fungsi dan daya guna bahasa dalam kaitannya dengan faktor ekstralingualnya (ekonomi, pendidikan, keturunan, pergaulan sosial, dan religiusitas). Dalam karya ini, Sudaryanto (1991) cenderung dan yakin bahwa kemampuan penggunaan bahasa Jawa pada ranah keluarga lebih ditentukan dengan persoalan cita rasa afektif atau ekspresi jati diri. Sehingga penguasaan bahasa Jawa di ranah keluarga dibedakan atas dua tahap, yakni: tahapan uyon-uyon dan tahapan tapa brata.

Tahapan uyon-uyon adalah tahapan yang menganggap priyagung ningrat (aristrokat) sebagai role-model bagi perilaku linguistik. Tahapan tapa-brata adalah tahapan yang mengandalkan akan perilaku dan jati diri kejawaannya sendiri dan tidak mempedulikan lagi priyagung ningrat sebagai role-model. Akibat dari penguasaan bahasa 
yang berawal pada tahapan tapa-brata adalah munculnya keanekaragaman (tidak ada keseragaman) penguasaan bahasa.

Subroto (2006) mengungkapkan bahwa lingkungan keluarga dan masyarakat merupakan lingkungan terdekat anak dalam mempelajari bahasa Jawa sebagai bahasa ibu atau bahasa pertama secara tidak langsung. Ranah keluarga merupakan instansi pertama tempat membentuk sikap positif generasi muda Jawa terhadap bahasa Jawa. Pembinaan bahasa Jawa secara terpadu berada pada ranah keluarga (rumah tangga), ranah masyarakat, dan ranah persekolahan (pendidikan). Dari ketiga ranah tersebut ternyata ranah keluarga atau rumah tangga menduduki posisi sentral. Hal ini menyiratkan bahwa keluarga merupakan ranah yang mula pertama dan yang utama melakukan "pembelajaran" bahasa Jawa bagi anak-anak Jawa sebagai bahasa ibu atau bahasa pertama. Urutan selanjutnya pada ranah masyarakat dan kemudian pendidikan.

Sudjati (1977) meneliti bahasa Jawa yang digunakan di kotamadya Semarang. Penelitian tersebut belum sepenuhnya mencerminkan studi dialek, hanya beberapa leksikon saja yang ditampilkan dalam analisisnya, terutama leksikon umpatan, yang dianggapnya sebagai ciri kedialekan lokal Semarang. Tampaknya penelitian yang dilakukan oleh Sudjati lebih cenderung pada tekanan bunyi akhir suatu kata "idiolek Semarangan". Penelitian ini juga menyinggung sepintas tentang ketidakmampuan penutur Semarang dalam bertutur krama (inggil). Pernyataan yang terakhir inilah yang perlu ditindaklanjuti dalam penelitian berikutnya untuk bahan rujukan atau pertimbangan.

\section{Metode Penelitian}

Lokasi penelitian berada di Kota Semarang, wilayah penelitian yang dibidik adalah keluarga Jawa yang tinggal di perkampungan. Adapun area dalam penelitian adalah di dua kampung, yakni Kampung Tandang dan Mrican, Kecamatan Semarang Selatan

Data yang dikumpulkan dalam penelitian ini adalah tuturan yang terjadi dalam berbagai macam peristiwa tutur, berlangsung secara natural. Metode yang dipakai untuk mengumpulkan data adalah metode simak dan metode cakap. Metode simak meliputi observasi, catat dan rekam. Sedang metode cakap meliputi partisipan dan wawancara.

Data yang diperoleh akan dianalisis berdasarkan watak dan perilakunya. Transkripsi data lingual akan dianalisis menggunakan metode deskriptif kualitatif. Data 
akan dianalisis berdasarkan kaidah alternasi (Ervin-Tripp, 1972). Pemilihan dan penempatan leksikon sesuai kaidah formalitas, yang juga memperhatikan faktor sosial budaya yang berlaku, yang membentuk pola tuturan di dalam masyarakat tutur.

Setalah data dianalsis, kemudian dilakukan verifikasi. Verifikasi yaitu pemeriksaan atau pengecekan kebenaran hasil analisis data yang telah dilakukan (Moleong, 2006; Sutopo, 2006). Pemeriksaan ini sangat penting, karena dapat dipandang sebagai alat kontrol untuk menentukan benar atau tidaknya hasil analis data yang telah dilakukan.

\section{Hasil dan Pembahasan}

Kedudukan Bahasa Jawa

Bertolak dari kekuatan yuridis formal yang dinyatakan di dalam UUD 1945 Bab XV, Pasal 32, sebagai berikut.

"Negara memajukan kebudayaan Nasional Indonesia di tengah peradaban dunia dengan memelihara dan mengembangkan nilai-nilai budayanya, dan negara menghormati dan memelihara bahasa daerah sebagai kekayaan budaya nasional".

Dapat dinyatakan bahwa bahasa Jawa berposisi sebagai bahasa kedua bila dibandingkan dengan bahasa Indonesia. Meskipun, bahasa Jawa memiliki cakupan wilayah yang cukup luas dan jumlah penutur yang cukup besar, lebih dari 80 juta (KBJ IV, 2006; Nothofer, 1987 dan 1982). Namun, tetap berkedudukan sebagai bahasa daerah.

Adapun fungsi utama bahasa Jawa sebagai bahasa daerah adalah sebagai alat komunikasi di lingkungan keluarga dan masyarakat Jawa, alat penyampai dakwah secara lokal, alat pengungkap seni tradisi dan seremonial Jawa. Dengan kata lain, bahasa Jawa hanya sebagai penanda jatidiri/identitas masyarakat Jawa (Subroto, 2006:164-165).

Akibat kedudukan dan persaingan posisi tersebut muncullah persoalan, sebagai berikut. Posisi bahasa Jawa terdesak dan akibatnya minat untuk menggunakan bahasa Jawa semakin berkurang. Muncul keengganan untuk berbahasa Jawa, terutama bentuk halus (krama dan krama inggil). Muncul asumsi bahwa belajar bahasa Jawa lebih sulit ketimbang bahasa Indonesia dan Inggris.

\section{Peran Keluarga Jawa terhadap Penggunaan Bahasa Jawa}

Keluarga Jawa memiliki peran yang kuat sebagai penentu awal terhadap penggunaan bahasa bagi anggota keluarganya, terutama bagi anak turunannya (pewaris alur kekerabatan). Keluarga memiliki peran penting sebagai lembaga informal dalam pewarisan 
bahasa. Sebagai kendali kemudi berada pada orang tua. Peran orang tua sebagai kunci utama penggunaan dan pemilihan bahasa yang akan digunakan pada keluarga tersebut. Peran orang tua sangat terasa manakala perkawinan tersebut memiliki latar belakang suku dan bahasa yang berbeda. Rangkaian ikatan tersebut dapat diabstraksikan sebagai berikut.

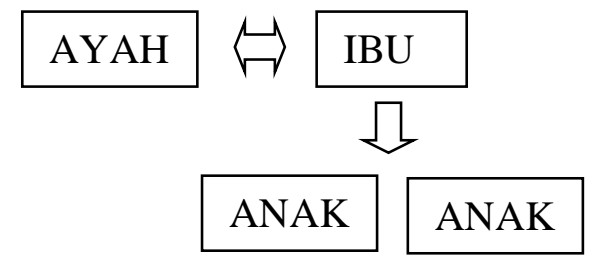

Keterangan:

Ayah ibu sebagai orang tua memiliki peran yang sama dalam menentukan pilihan bahasa ( $\Rightarrow$ ), pada saat pewarisan, pada umumnya atau lebih seringnya, seorang ibu lebih berperan dalam pemilihan dan penentuan bahasa bagi anak-anaknya.

Peran keluarga Jawa dalam kedudukannya sebagai lembaga informal penggunaan bahasa, memiliki peran sebagai pintu gerbang pengenalan, pembelajaran, dan pelestarian bahasa Jawa. Tiga peran inilah yang dapat mengamankan posisi bahasa Jawa sebagai bahasa ibu bagi penutur Jawa, sekaligus pengikat emosi, naluri dan kepribadian sebagai jati orang Jawa yang njawani. Ketiga peran tersebut, dideskripsikan di bawah ini sesuai dengan fenomena yang terjadi saat ini.

\section{Peran Keluarga Jawa sebagai Pintu Gerbang Pengenalan Bahasa Jawa}

Keluarga Jawa memiliki peran sebagai pintu gerbang pengenalan bahasa Jawa, karena melalui keluarga Jawa inilah bahasa Jawa mulai dikenalkan sekaligus diajarkan kepada generasi muda sebagai pewaris utama kelangsungan bahasa Jawa. Melalui lembaga keluarga Jawa inilah bahasa Jawa meniti kelangsungan keberadaannya. Dengan kata lain, kehidupan bahasa Jawa terletak pada kemauan keluarga Jawa itu menggunakan bahasa Jawa sebagai bahasa ibunya. Melalui bahasa ibu itulah bahasa Jawa memiliki multifungsi, yakni sebagai berikut, (1) pengikat erat emosi dalam kekerabatan, (2) identitas diri, (3) alat komunikasi antaretnik Jawa.

\section{Peran Keluarga Jawa sebagai Pintu Gerbang Pembelajaran Bahasa Jawa}

Keluarga Jawa memili peran sebagai pintu gerbang pembelajaran bahasa Jawa. Melalui dari lingkungan keluarga inilah terjadi proses pembelajaran alami, yakni pembelajaran pewarisan penggunaan bahasa Jawa antara orang tua dengan anak (antara generasi yang satu kepada generasi berikutnya). Tahap pembelajaran di lingkungan keluarga inilah 
terjadinya salah satu letak penentu penggunaan bahasa Jawa yang sebenarnya sebagai cermin adanya "bentuk" bahasa Jawa saat ini.

Adapun pola pembelajaran bahasa Jawa, dapat diabstraksikan di bawah ini, yakni bermula dari ranah keluarga, selanjutnya dkembangkan melalui ranah masyarakat, diteruskan dengan warna pada ranah penedidikan, dan juga ranah pekerjaan berperan pula dalam penguasaan bahasa sesuai dengan keperluan dan eksistensi penuturnya.

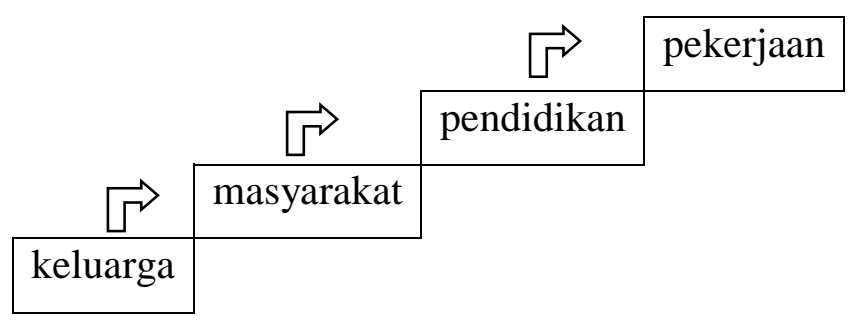

\section{Peran Keluarga Jawa sebagai Pintu Gerbang Pelestarian Bahasa Jawa}

Keluarga Jawa selain berperan sebagai pintu gerbang pengenalan dan pembelajaran bahasa Jawa, juga memiliki peran yang tidak kalah pentingnya, yakni sebagai pintu gerbang pelestarian bahasa Jawa. Melalui peran sebagai pintu gerbang pelestarian inilah bahasa Jawa bakal akan digunakan atau justru akan ditinggalkannya. Manakala bahasa Jawa dapat digunakan secara baik maka akan dapat menyatu dengan ikatan emosional. Maka akan terjadi proses pelestarian.

Model pelestarian ini memiliki kekuatan yang berkelanjutan, yakni memperkokoh posisi bahasa Jawa sebagai bahasa ibu. Manakala bahasa Jawa mulai ditinggalkan berarti awal gagalnya pelestarian dan kehidupan bahasa Jawa mulai terancam.

Bahasa Jawa selayaknya digunakan sebagai perekat emosi kekekerabatan dalam kehidupan sehari-hari keluarga Jawa. Dengan demikian, bahasa Jawa digunakan untuk menyampaikan maksud/kehendak, menyalurkan kasih sayang dalam keharmonisan keluarga, dan mempererat internal keluarga. Meskipun pemakaian bahasa Jawanya terlepas dari hirarkhi tuturan.

\section{Bentuk Penggunaan Bahasa Jawa pada Ranah Keluarga Jawa Wilayah Perkampungan}

Bentuk penggunaan bahasa Jawa yang berkembang saat ini, terutama di wilayah perkampungan, dapat ditengarai sebagai bentuk pemakaian bahasa Jawa kekinian. Bentuk tuturan Jawa, yang kerapkali muncul, sebagai berikut.

(1) Aku pek tindak dewe wae ya. 'Aku akan berangkat sendiri saja ya.'

(2) Sing siram Bapak apa aku sik 'Yang mandi Bapak atau aku dulu.' 
(3) Bu, aku ngagem seragam batik wae. 'Bu, aku memakai seragam batik saja'

Bentuk tuturan (1-3) di atas, ditemukan di lingkungan keluarga perkampungan: Tandang, Mrican. Kerapkalinya tipe tuturan tersebut muncul dalam peristiwa tutur, maka muncul asumsi terutama pada penutur muda perkampungan bahwa bentuk tuturan tersebut sebagai bentuk yang benar dan tepat atau sebaliknya sebagai bentuk yang kurang benar dan kurang tepat atau justru sebagai bentuk yang mewaliki warna sendiri (dialektis), sebagai tuturan pesisiran atau tuturan Semarangan.

Bentuk tuturan (1-3) di atas merupakan cerminan wujud bahasa Jawa yang terjadi saat ini. Bentuk tuturan itulah yang didengar dan diajarkan orang tua kepada anaknya, serta dilakukan secara terus menerus sehingga menjadi kebiasaan dalam bertutur. Secara deskriptif empiris ujaran pada peristiwa tutur (1-3) adalah berterima, namun secara preskriptif normatif diangapnya sebagai tuturan bahasa Jawa yang tidak tepat.

Ketidakberterimaan secara preskriptif normatif terletak pada penempatan kosakata krama inggil dalam tuturan. Leksikon krama inggil: tindak 'pergi', siram 'mandi', dan ngagem 'memakai', yang seharusnya ditujukan kepada mitra tuturnya tetapi justru digunakan untuk diri sendiri atau diri penutur.

Munculnya fenomena ini, sebagai akibat pembelajaran alami (natural) di lingkungan keluarga, yakni pembelajaran model stereotype, menirukan dan melakukan apa yang didengar dan dialami dalam lingkungan keluarga dan dilakukan terus menerus, sehingga tertanam dalam alam pikiran dan terikat dalam emosi. Bentuk tuturan lain yang kerapkali muncul di lingkungan keluarga perkampungan, antara lain sebagai berikut.

(4) $\mathrm{Bu}$, adik dahar sik nggih. 'Bu, adik makan dulu ya'

(5) $B u$, mangke kula tindak radi gasik. 'Bu, nanti saya pergi agak awal'

(6) Nderek pamit, kula nembe gerah. 'Minta izin, saya baru sakit'

Model tuturan (4-6) pun bila diukur berdasar parameter kaidah normatif tidak dibenarkan. Fakta empirik, model tuturan kramanisasi diri dapat diterima oleh komunitas penutur Semarang, bahkan ditengarai sebagai bahasa Jawa Semarangan.

\section{Rendahnya Peran Keluarga dalam Berbahasa Jawa}

Rendahnya peran keluarga dalam berbahasa Jawa, ditandai dengan keengganan menggunakan bahasa Jawa di lingkungan keluarga. Akibat keengganan dalam bertutur Jawa dapat berakibat rendahnya penguasaan kosakata Jawa, terutama pada tataran krama dan krama alus yang dianggap paling sulit. 
Kurang atau tidak adanya kebiasaan terhadap pemakaian bahasa Jawa di dalam kehidupan sehari-hari akan berdampak serius terhadap kelangsungan kehidupan bahasa Jawa. Gejala yang mulai muncul menandai terganggunya kelangsungan kehidupan bahasa Jawa, sebagai berikut. (1) Bahasa Jawa tidak lagi menjadi bahasa yang rekat dengan emosi dan jiwa penuturnya. Kedudukan bahasa Jawa mulai digeser dengan bahasa Indonesia. (2) Kurang bangga terhadap bahasa ibunya, ada unsur malu dalam menggunakan bahasa Jawa, dianggapnya kurang berpretise, dan lambat laun akan menjadi asing bagi penuturnya. (3) Muncul anggapan penggunaan bahasa Jawa tidak memiliki relasi terhadap peningkatan ekonomi.

Fenomena di atas diperkuat oleh pernyataan penutur Jawa di Kota Semarang, yakni:

"Dalam hati saya sebenarnya sangat sedih tidak bisa mengajari anak saya dengan bahasa Jawa yang baik. Tidak perlu benarlah yang penting baik. Bagaimana bisa benar saya sendiri juga tidak pandai dengan bahasa Jawa. Bila tidak bisa krama ya ngoko saja ndak apa-apa, yang penting halus dan ada rasa menghormati. Bahasa Jawa itu dapat menempatkan diri "empan papan", kapan bicara, dimana dengan siapa itu dibedakan" (Tiani, 11 Februari 2017).

Kutipan di atas sebagai perwakilan keprihatinan orang tua terhadap rendahnya kemampuan penggunaan bahasa Jawa pada generasi muda. Penggunaan bahasa Jawa berbanding lurus dengan kehalusan budi dan kesopanan. Hakiki inilah yang masih sangat diperlukan oleh para kaum orang tua sebagai sarana pembelajaran budi pekerti bagi anakanaknya.

\section{Simpulan}

Peran keluarga sangat berpengaruh terhadap penguasaan dan penggunaan bahasa Jawa saat ini. Kehidupan bahasa Jawa saat ini (bahasa Jawa kekinian) tidak dapat dilepaskan dari peran keluarga. Keluarga sebagai lembaga informal memiliki tiga peran terhadap penggunaan bahasa Jawa sebagai bahasa ibu. Tiga peran keluarga terhadap penggunaan bahasa Jawa, yakni (1) pintu gerbang pengenalan bahasa Jawa, (2) pintu gerbang pembelajaran bahasa Jawa, dan (3) pintu gerbang pelestarian bahasa Jawa.

Peran keluarga Jawa perkampungan terhadap penggunaan bahasa Jawa cukup rendah, yang ditandai dengan (1) kurang mengajarkan bahasa Jawa secara tepat dalam 
kehidupan sehari-hari dan (2) rendahnya penguasaan kosakata Jawa, terutama pada tataran krama dan krama inggil.

\section{Daftar Pustaka}

Bernstein, Basil. 1972. Social Class, Language and Socialization. London: Routledge and Paul.

Calefato, Patrizia. 2009. 'Language in Social Reproduction: Sosiolinguistics and Sociosemiotics', Sign Systems Studies 37(1/2):43-81.

Ervin_Tripp, Susan M. 1972. "On Sociolinguistic Rules: Alternation and Cooccurence" dalam Directions in Sosiolinguistics: The Ethnography of Communication. Diedit oleh John Gumperz \& Dell Hymes. New York: Holt Rinehart \& Winston, 213-250.

Friedman, M.M. 1981. Family Nursing, Theory and Assessment. Connecticut: Appleton Century Crofts.

Goldenberg, I and H. Goldenberg. 1980. Family Therapy. Aint Louis: Cole Publishing Comp.

Leavitt, M.B. 1982. Families at Risk: Primary Prevention in Nursing Practice. Boston: Little, Brown and Comp.

Nothofer, Bernd. 1982. "Central Javanese Dialects" dalam Pacific Linguistics: Vol. 3/C76, pp. 287-309.

Nothofer, Bernd. 1987. "Cita-cita Penelitian Dialect" dalam Dewan Bahasa: Jurnal Pembinaan dan Pengembangan Bahasa. Jilid 31, Bilangan 2, pp. 128-149.

Purwoko, Herudjati. 2008. Jawa Ngoko: Ekspresi Komunikasi Arus Bawah. Semarang: Penerbit Indek.

Subroto, Edi. 2006. 'Pembinaan Bahasa Jawa di Ranah Keluarga, Masyarakat, dan persekolahan Secara Terpadu'. hal. 159-170, dalam Prosiding Kongres Bahasa Jawa IV: Komisi Pendidikan Formal. Semarang.

Sudaryanto 1991. "Bahasa Jawa: Prospeknya dalam Ketegangan antara Pesimisme dan Optimisme". Dalam Kongres Bahasa Jawa I. Semarang, 15-20 Juli 1991.

Tiani, Andista. 2017. "Keperihatinan Orang Tua terhadap Kemampuan Berbahasa Anak Sekarang" dalam Wawancara dengan Informan, Semarang, 11 Februari 2017. 